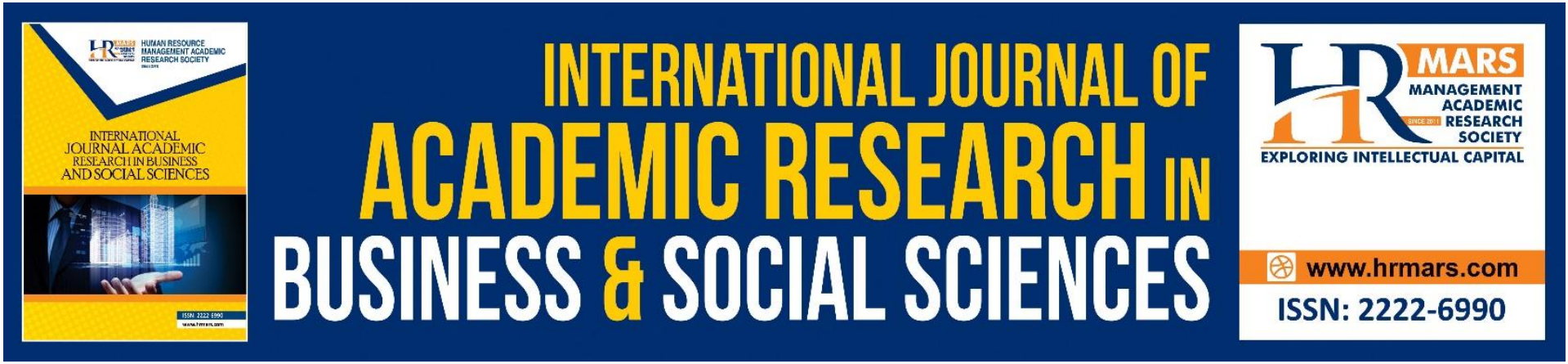

\title{
Malaysian Palm Oil Industry Performance During Epidemic Covid 19
}

\section{Azmirul Ashaari, Mazilah Abdullah and Nursyazwani Mohd Fuzi}

To Link this Article: http://dx.doi.org/10.6007/IJARBSS/v12-i1/12058

DOI:10.6007/IJARBSS/v12-i1/12058

Received: 06 November 2021, Revised: 08 December 2021, Accepted: 24 December 2021

Published Online: 12 January 2022

In-Text Citation: (Ashaari et al., 2022)

To Cite this Article: Ashaari, A., Abdullah, M., \& Fuzi, N. M. (2022). Malaysian Palm Oil Industry Performance During Epidemic Covid 19. International Journal of Academic Research in Business and Social Sciences, $12(1), 622-628$.

\section{Copyright: (c) 2022 The Author(s)}

Published by Human Resource Management Academic Research Society (www.hrmars.com)

This article is published under the Creative Commons Attribution (CC BY 4.0) license. Anyone may reproduce, distribute, translate and create derivative works of this article (for both commercial and non0-commercial purposes), subject to full attribution to the original publication and authors. The full terms of this license may be seen at: http://creativecommons.org/licences/by/4.0/legalcode

\section{Vol. 12, No. 1, 2022, Pg. $622-628$}

Full Terms \& Conditions of access and use can be found at http://hrmars.com/index.php/pages/detail/publication-ethics 


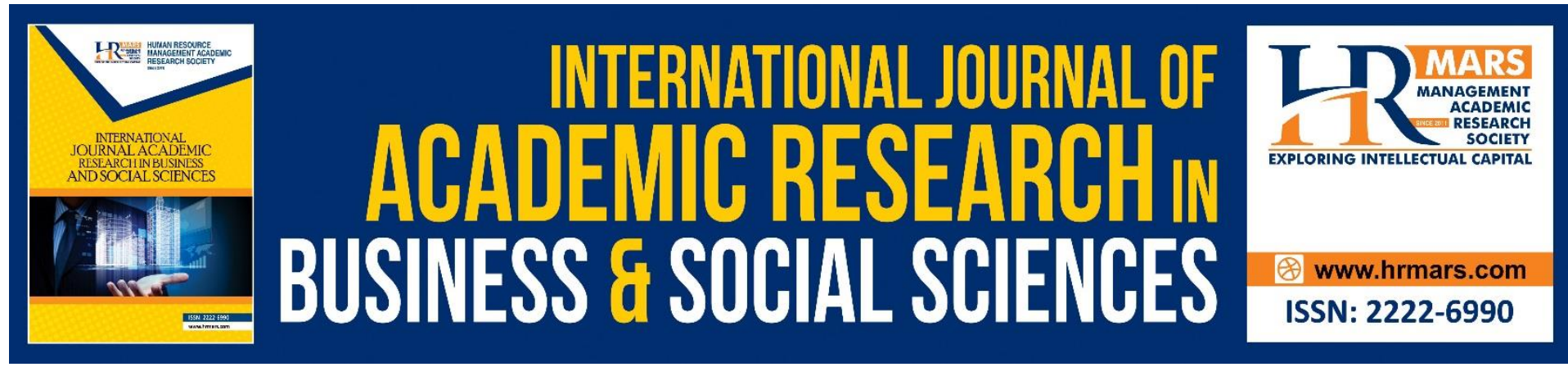

\title{
Malaysian Palm Oil Industry Performance During Epidemic Covid 19
}

\section{Azmirul Ashaari ${ }^{1}$, Mazilah Abdullah² and Nursyazwani Mohd $\mathrm{Fuzi}^{3}$}

1,2Department of Business Administration, Azman Hashim International Business School, Universiti Teknologi Malaysia, 81310 Johor Bahru, Johor, MALAYSIA, ${ }^{3}$ Department of Accounting and Finance, Azman Hashim International Business School, Universiti Teknologi Malaysia, 81310 Johor Bahru, Johor, MALAYSIA.

${ }^{1}$ Corresponding Author: Azmirul Ashaari

Email: azmirul@utm.my

\begin{abstract}
The epidemic of Covid-19 has a significant impact on demand for vegetable oils, especially palm oil. On a worldwide scale, numerous countries have implemented lockdowns, resulting in the closure of businesses, including the transportation and food industry. Malaysian palm oil industry is primarily reliant on manual labour. Due to total lockdown, workers have suffered many kinds of impacts that affected significantly on the production of palm oil in Malaysia. It also causes the supply chain of palm oil to be disrupted and having a shortage. Hence, current research aims to review the performance of the Malaysian palm oil industry during the epidemic. This research also identifies the impact of epidemic Covid 19 on the Malaysian palm oil industry. This research may help agencies and parties related to the Malaysian palm oil industry to overview and plan the industry sustainability.
\end{abstract}

Keywords: Palm Oil, Industries, Production, Price Market, Strategic Planning

\section{Introduction}

In 1870, palm oil was first introduced in Malaysia (Nambiappan et al., 2018) and continued to thrive with transformative technologies. Currently, palm oil has become one of the significant industries that contribute to the economic growth of Malaysia. However, since the pandemic, palm oil sales have nosedived and stabilized, following the pattern of increasing Covid 19 cases Report that includes the sales, demand and how the pandemic affected palm oil sales indicated that the major industry sector primarily affected based on production and extraction of raw materials is palm oil production. Palm oil is used to produce cooking oil, soap, and candles. With the raised of planters' productivity and competitiveness, Malaysia has also become one of the significant suppliers of palm oil to China, India, Holland, Pakistan, Philippines, Turkey, the USA, Kenya, South Korea, and Italy (Mahat, 2012). Consequently, Malaysia is the second biggest exporter of palm oil worldwide. In 2020, Malaysia accounted for 25.8 per cent and 34.3 per cent of the world's palm oil output and exports. Figure 1 shows the amount in tons of palm oil production produced by Malaysia. 


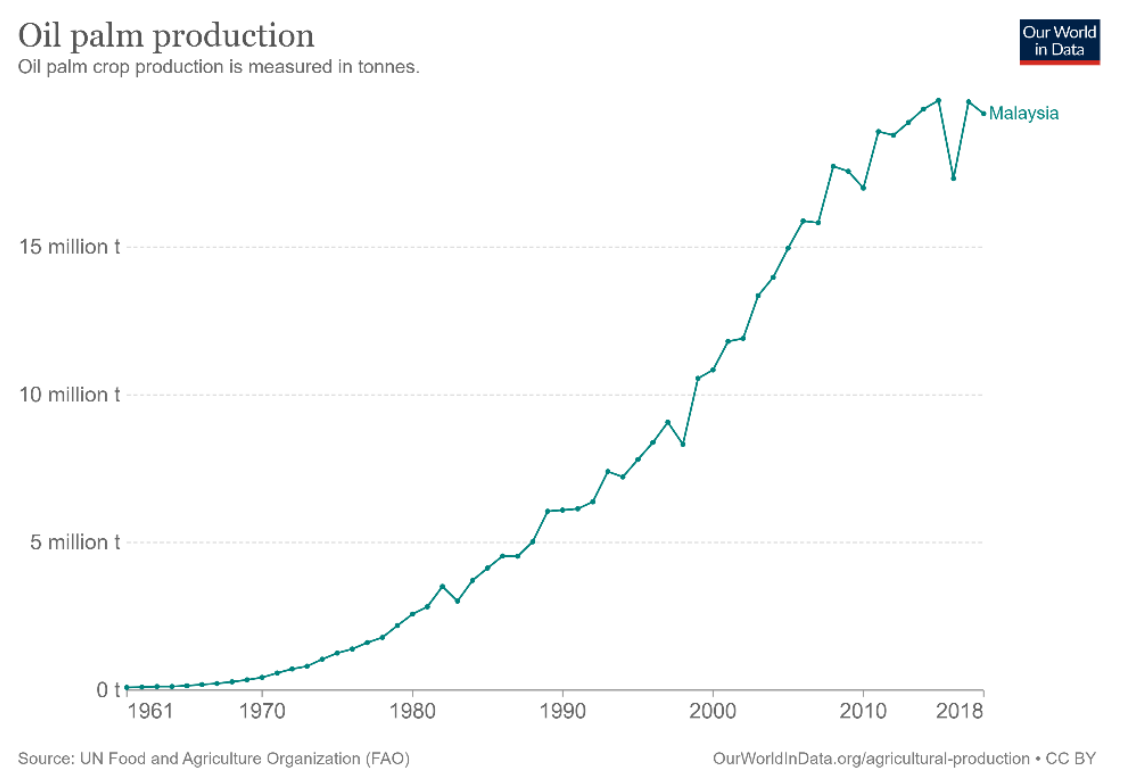

Figure 1. Malaysia palm oil production from 1961 until 2018 (Ritchie \& Roser, 2021)

\section{Palm Oil Industries}

The first batch of palm oil trees planted in Malaysia was early 1870 by the British. The palm oil tree is taken from West Africa. In 1917, the first commercially planting location in Malaysia was at the Tenanmaran Estate in Selangor. It has become the foundation of the palm oil industry in Malaysia (Nambiappan et al., 2018). In 1960, the government-organized agricultural diversification program caused the oil palm to increase significantly to reduce the 'country's economic dependence on rubber and tin. Most of the Malaysian oil palm plantations are under estate management and independent smallholder scheme. Hence, the government also introduced land settlement schemes for planting oil palm. The mature oil palm tree can reach sixty feet or more in height. The appearance of the palm oil tree was looking rough because of the fronds wrapped on the treey. However, the palm oil tree does not bear fruit in the early 30 months after being planted. It will start producing fresh fruits bunches and continue to be productive for the next 20 to 30 years; this ensure the sustainability of the supply chain is consistent. Typically, most of the Malaysia oil palm tree is the tenera type. It is a hybrid of dura and pisifera (Ooi et al., 2016). The palm oil tree will bear both male and female flowers on the same tree, called a monoecious crop. A single tree will produce around 10 to $25 \mathrm{~kg}$ compact bunches, and each bunch may have 1000-3000 fruits.

Malaysia accounted for $25.8 \%$ for palm oil production and $34.3 \%$ for world exports in 2020. Malaysia also accounted for $9.7 \%$ and $19.7 \%$ of the 'world's total production and exports of oils and fats in 2020. The palm oil industry contributed $37.7 \%$ of the Growth Domestic Product (GDP) to the agricultural sector in 2020 (Refinitiv, 2021). Moreover, the palm oil industry also contributed to the country's employment, with around 1 million people working directly or indirectly in the oil palm industry.

However, the price of palm oil fluctuates all the time depending on various internal and external factors and world volatility. For example, global economic growth will influence the demand for palm oil from other countries such as India and Europe. The foreign exchange rate of Ringgit Malaysia is also an internal factor for the unstable export price of palm oil. Based on the demand-supply theory, the palm oil price will increase when the demand has increased, creating a fluctuations trend in the Malaysian palm oil industry Generally, as price 
increases, companies are willing to supply more and vice versa when the price falls. Thus, in order to maintain the demand for palm oil from Malaysia, the government need to determine several factors affecting palm oil price and take mitigation action to maintain the export market share of palm oil.

\section{Malaysian Palm Oil Price}

In Malaysia, palm oil has become significant commodities for the export crop. Figure 2 shows the palm oil price from January 2020 to February 2021. In February 2020, the monthly price of palm oil is RM3,406.83, which fell drastically to RM30,35.28. After that, the price declined by around $10.91 \%$ to RM2,733.56 in March 2020. This is followed by a decrease of $2.99 \%$ to RM2,651.88 in April 2020. The price plummeted considerably in April. In May 2020, palm oil prices were the lowest throughout the year, at RM2,504.71. In addition to the downturn, the price increases to RM2,806.79 amounted to around 12,06\% in June 2020, compared to May 2020. Later, in July, the price grew steadily to RM2,959.72 (5.45\%). In August 2020, the figure stands at RM3,181.16 (7,65\%), September 2020; RM3,305.09 (3,73\%) and October 2020; RM3,402.78 (2.96\%). In November 2020, the price jumped considerably to RM3,779.19 (11.06\%). In December 2020, the price increases 9.27\%, reaching the maximum price of RM4,129.47. Later in 2021, the monthly price for palm oil was RM 3,997.72 (3.19\%), showing a decrease in the first month of January 2021 compared to the previous month. Eventually, in February 2021, palm oil prices jumped to RM4.116,12, an increase of $2.96 \%$ more than in January 2021.

Malaysia is still the world's benchmark for global stocks of Crude Palm Oil (CPO) products and their derivatives. Malaysia's expertise in presenting data related to the development of palm oil production and price, offers updated and accurate stock information than other countries. Even with the recognition as country with a high production rate and the second-largest producer of palm oil globally, the price of palm oil in Malaysia still stabilized and fluctuated with the income. However, it inhibited the increase in Crude Palm Oil (CPO) prices during the outbreak of COVID-19 in India, led to the implementation of a lockdown. Moreover, demand from China remain the primary factor determining the demand for CPO and a triggering factor that pushes up CPO prices, based on the data of Malaysian palm oil exports.

The palm oil market factors come into play when the shortfall in production has led to supply disruptions as demand outstrips supply. Due to its nature of having more diversified end-uses, the palm has the second-largest source of edible oil, next only to soybean and other oilseeds. Today, the oils palm industry is facing a few challenges: trade barriers, weakening currency of importing countries, ban on palm oil usage in biofuel by some Western countries, and the anti-palm oil campaign. 


\section{Palm oil Price from January 2020 to February 2021}

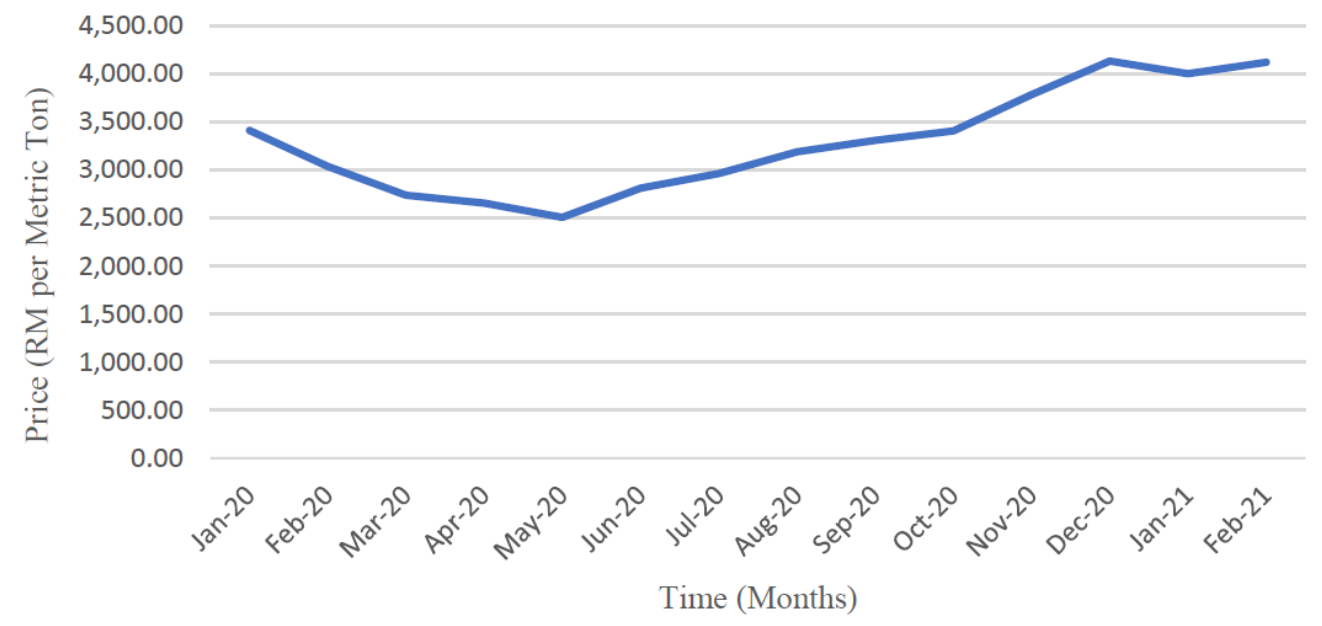

Figure 2. Palm Oil Price from January 2020 to February 2021 (Refinitiv, 2021)

These obstacles affect the trade of palm oil in the global market. The effect on the economy is severe as it reduces government revenues, affect production costs, and increase unemployment rate. This outcome occurred when the palm oil companies loss in business or revenues drop. In this situation, the needs to reduce the production cost has always been expected as the solution. The victim usually will generally be the employees first. Consequently, the unemployment rate in Malaysia will increase, along with the total revenue for Malaysia decrease.

\section{The Factors and Impact by Covid 19 in Palm Oil Industry}

A similar pattern is seen in Indonesia. As the first exporter of palm oil worldwide, Indonesia is also having a drastic fall in markets. In January 2020, China reduced the export of palm oil to 57\% (Refinitiv, 2021). The demand has fallen tremendously within the start of the year, and with exports falling, the industry is expected to take a nosedive. This is because the lack of exports cut off the revenue towards the industry due to the pandemic halting the global economy to a slow down. Currently, China, one of the significant imports of palm oil than other countries, has closed off from the rest of the world, keeping its borders closed and turning inward. Similarly, India currently heavily relies on vegetable oil. These events have caused the demand for palm oil to be reduced to $65 \%$ (Go and Lau, 2021).

In addition, the epidemic of Covid 19 has had a significant impact on the market for vegetable oils, particularly palm oil. As a result of the existing new norm, consumers' nutritional choices have evolved towards eating at home rather than dining at restaurants and cafés (Hashim et. al., 2021). Many restaurants have been closing during epidemic, resulting in a decrease demand for palm oil users.

Palm oil plantation workers have also been affected due to lockdowns in Malaysia. Palm oil plantations are experiencing job losses due to social distancing, self-isolation and travel bans enforced to avoid the spread of Covid-19. In Sabah, palm oil and milling operations have been stopped in six districts. Sabah is one of the largest palm oil producers in Malaysia (Lee, 2021). These halts could lead to a monthly national production loss of up to $20 \%$ a month. Crowley (2020) describes that the Malaysian country's plantation industry, particularly the oil palm business, was short 500,000 jobs due to a suspension in recruitment attempts. Palm oil production dropped to 3.8 per cent in 2020. It reduced from 19.85 million 
metric tons in 2019 to 19.14 million metric tons in 2020. In 2021, Crude Palm Oil (CPO) costs leapt to a high as RM4,247.50 per ton, contrasted with the last record of RM4,193 per ton, the most elevated since 13 years prior. The pandemic influences the worldwide economy, especially Malaysia, straightforwardly influencing production and demand, creating supply chain and market disturbance, and carrying monetary effects on firms and monetary business sectors.

\section{Conclusion}

The palm oil industry is one of the crucial sectors in the Malaysian economy. This research has successfully presented the overview and price changes in palm oil products due to the epidemic of Covid-19. In 2020, the palm oil price fluctuated parallel to the Covid-19 pandemics that started in March 2020. The outbreak of Covid-19 affected Malaysia's palm oil plantations and led to some plants' closure. This led to a shortage of labour, which contributed to the rise in commodity prices. The low stock resulted in higher CPO prices and vice versa. The low demand in imports has caused a decline in palm oil stocks that eventually dropped the palm oil prices. However, Malaysia's palm oil industry has started to recover in 2021 due to the vaccine Covid-19. The only way to return the normal and keep improving is by vaccinating all workers in the palm oil industry. This research may help agencies and parties related to the Malaysian palm oil industry to overview the current issue and challenges in the palm oil industry due to Covid-19.

\section{Acknowledgements}

The authors acknowledge the support of Azman Hashim International Business School (AHIBS), Universiti Teknologi Malaysia (UTM), and Ministry of Higher Education Malaysia (MOHE) Fundamental Research Grants FRGS/1/2020/STG06/UTM/02/9.

\section{References}

Council, M. P. O. (2019). MPOC Aannual Rreport 2019.

Crowley, M. Z. (2020). Foreign labor shortages in the Malaysian palm oil industry: Impacts and recommendations. Asian Journal of Agriculture and Development, 17(1362-2020-1833), 1-18.

Go, Y. H., \& Lau, W. Y. (2021). Extreme risk spillovers between crude palm oil prices and exchange rates. The North American Journal of Economics and Finance, 58, 101513.

Hashim, J. H., Adman, M. A., Hashim, Z., Radi, M. F. M., \& Kwan, S. C. (2021). COVID-19 Epidemic in Malaysia: Epidemic Progression, Challenges, and Response. Frontiers in Public Health, 9.

Lee P. O. (2021). Saleable and Sustainablesustainable: Sabah takes the lead in palm oil certification in Malaysia. The Institute of Southeast Asian Studies (ISEAS), 106. , ISSN 2335-6677

Mahat, S. B. A. (2012). The palm oil industry from the perspective of sustainable Developmentdevelopment: A case study of Malaysian Palm Oil Industry. Graduate School of Asia Pacific Studies, Ritsumeikan Asia Pacific University of Japan.

Nambiappan, B., Ismail, A., Hashim, N., Ismail, N., Nazrima, S., Idris, N. A. N., ... \& Kushairi, A. (2018). Malaysia: 100 Years of resilient palm oil economic performance. Journal Of of Oil Palm Research, 30(1), 13-25. 
Ooi, L. C. L., Low, E. T. L., Abdullah, M. O., Nookiah, R., Ting, N. C., Nagappan, J., ... \& Singh, R. (2016). Non-tenera contamination aAnd tThe economic impact oOf SHELL genetic testing iln tThe Malaysian Independent Oil Palm Industry. Frontiers in Plant Science, 7, 771.

Refinitiv. (2021). Palm oil supply aAnd demand outlook half year report 2021.

Ritchie, H., \& Roser, M. (2021). Forests and Deforestationdeforestation. Our World in Data. 